\title{
Impact of Trichloroethylene Exposure on the Microbial Diversity and Protein Expression in Anaerobic Granular Biomass at $37^{\circ} \mathrm{C}$ and $15^{\circ} \mathrm{C}$
}

\author{
Alma Siggins, ${ }^{1}$ Anne-Marie Enright, ${ }^{1}$ Florence Abram, ${ }^{2}$ \\ Catherine Botting, ${ }^{3}$ and Vincent $\mathrm{O}^{\prime}$ 'Flaherty ${ }^{1}$ \\ ${ }^{1}$ Microbial Ecology Laboratory, Department of Microbiology, School of Natural Sciences, National University of Ireland, Galway, Ireland \\ ${ }^{2}$ Functional Environmental Microbiology, Department of Microbiology, School of Natural Sciences, \\ National University of Ireland, Galway, Ireland \\ ${ }^{3}$ BSRC Mass Spectrometry Facility, University of St Andrews, St Andrews KY16 9ST, UK
}

Correspondence should be addressed to Vincent O’Flaherty, vincent.oflaherty@nuigalway.ie

Received 13 July 2012; Accepted 14 September 2012

Academic Editor: Michael Hoppert

Copyright () 2012 Alma Siggins et al. This is an open access article distributed under the Creative Commons Attribution License, which permits unrestricted use, distribution, and reproduction in any medium, provided the original work is properly cited.

\begin{abstract}
Granular biomass from a laboratory-scale anaerobic bioreactor trial was analysed to identify changes in microbial community structure and function in response to temperature and trichloroethylene (TCE). Two bioreactors were operated at $37^{\circ} \mathrm{C}$, while two were operated at $15^{\circ} \mathrm{C}$. At the time of sampling, one of each temperature pair of bioreactors was exposed to process failure-inducing concentrations of TCE $\left(60 \mathrm{mg} \mathrm{L}^{-1}\right)$ while the other served as a TCE-free control. Bacterial community structure was investigated using denaturing gradient gel electrophoresis (DGGE) and 16S rRNA gene clone library analysis. Temperature was identified as an important factor for bacterial community composition, while minor differences were associated with trichloroethylene supplementation. Proteobacteria was the dominant phylum in all bioreactors, while clone library analysis revealed a higher proportion of Bacteroidetes-, Chloroflexi-, and Firmicutes-like clones at $15^{\circ} \mathrm{C}$ than at $37^{\circ} \mathrm{C}$. Comparative metaproteomics in the presence and absence of TCE was carried out by two-dimensional gel electrophoresis (2-DGE), and 28 protein spots were identified, with putative functions related to cellular processes, including methanogenesis, glycolysis, the glyoxylate cycle, and the methyl malonyl pathway. A good agreement between metaproteomic species assignment and phylogenetic information was observed, with 10 of the identified proteins associated with members of the phylum Proteobacteria.
\end{abstract}

\section{Introduction}

Anaerobic digestion $(\mathrm{AD})$ is a sequential and cooperative microbial process, employed in engineered ecosystems for the treatment of wastes and wastewaters and for the production of biogas from biomass and organic residues [1]. Low-temperature operation of laboratory-scale anaerobic digesters has been proven feasible as a cost-effective alternative to traditional mesophilic operating temperatures for a wide range of wastewater types $[2,3]$. At all applied temperature ranges, $\mathrm{AD}$ relies on the appropriate combination of a variety of microorganisms; complex syntrophic interactions between archaeal and bacterial species are essential for the complete degradation of organic compounds to methane [4]. In the past two decades, the nature of the microbial communities involved in low temperature $\mathrm{AD}$ has come under closer scrutiny, with the recognition that greater understanding of the potential and limitations of the microbial consortium could aid in process optimisation. For example, Enright et al. [5] demonstrated that a shift in methanogenic community structure observed by terminal restriction fragment length polymorphism (TRFLP) corresponded to increased hydrogenotrophic activity, while Bialek et al. [6] used statistical analysis (moving window/nonmetric multidimensional scaling) of quantitative polymerase chain reaction (qPCR) data to visualise shifts in the methanogenic communities that could be attributed to bioreactor configuration. Both of these studies, as is traditional for investigation of the microbial communities underpinning the process of anaerobic digestion, focused on the methanogens, a group of 
anaerobic archaea involved in the conversion of acetate and hydrogen to methane [7]. The low biodiversity associated with methanogens in $\mathrm{AD}$ has facilitated the generation of functional and process-relevant information based on methanogenic community structure [8].

We have previously documented the response of the methanogenic community within anaerobic granular biomass to the presence of trichloroethylene (TCE; [9]). TCE is a potentially carcinogenic and mutagenic compound [10], which is routinely employed in the cleaning and metal degreasing industries, and can be completely dechlorinated by the process of anaerobic digestion [11]. Our previous study[9] investigated the impact of influent TCE concentrations on the stable operation of expanded granular sludge bed bioreactors at $37^{\circ} \mathrm{C}$ and $15^{\circ} \mathrm{C}$. In order to explore the observed decrease in operational performance noted at both temperatures in response to an influent TCE concentration of $60 \mathrm{mg} \mathrm{L}^{-1}$, specific methanogenic activity (SMA) and toxicity batch assays, in addition to qPCR analysis of the methanogenic community, were undertaken [9]. We determined that changes in the methanogenic community in response to TCE were not sufficient to result in the observed process failure, while temporal sampling revealed that changes in temperature resulted in a higher impact on the methanogenic population structure [9]. Specific methanogenic activity and toxicity assays suggested that acetoclastic methanogens were reversibly inhibited by the presence of TCE and/or its degradation derivatives, while competition by dechlorinating organisms may have limited the availability of hydrogen for hydrogenotrophic methanogenesis [9]. Although our study [9] addressed the response of the archaeal community to the presence of TCE, no changes that could definitively account for bioreactor failure at that TCE concentration were identified. Conclusions from that study were based on metabolic groups rather than specific organisms, and disparities in results between molecular and physiological data were observed [9]. Consequently, this study attempts to further investigate the structural response of the bacterial domain, and the functional response of the overall microbial community.

This study investigated the impact of TCE on both the bacterial community structure (using DGGE and 16s rRNA clone library) and the microbial community function (using 2-DGE based metaproteomics) within $\mathrm{AD}$ bioreactors operating at $37^{\circ} \mathrm{C}$ and $15^{\circ} \mathrm{C}$.

\section{Materials and Methods}

2.1. Source of Biomass. Anaerobic granular sludge originating from four expanded granular sludge bed (EGSB) bioreactors was investigated. All bioreactors (R1-R4) were utilised for the treatment of a volatile fatty acid (VFA)-based wastewater. R1 and R2 were operated at $37^{\circ} \mathrm{C}$, while R3 and $\mathrm{R} 4$ were operated at $15^{\circ} \mathrm{C}$, with $\mathrm{R} 1$ and $\mathrm{R} 3$ supplemented with increasing concentrations of trichloroethylene (TCE; $\left.10-60 \mathrm{mg} \mathrm{L}^{-1}\right)$. The prepared influent was stored in a closed system to prevent volatilisation of TCE; a nitrogen filled gas bag was used to equilibrate the pressure as the influent was pumped from the storage container to the bioreactor. The bioreactor trial and associated performance data are presented in detail in Siggins et al. [9]. Biomass was sampled from the bioreactors on day 235, when influent TCE concentration of R1 and R3 were $60 \mathrm{mg} \mathrm{L}^{-1}$.

2.2. Volatile Fatty Acid (VFA) Analysis. Analysis of VFA concentrations of effluent samples collected from R1-R4 throughout the trial were performed by heated $\left(85^{\circ} \mathrm{C}\right)$ and agitated headspace, in a Varian Saturn 2000 GC/MS system, with CombiPAL autosampler (Varian Inc., Walnut Creek, CA). Separation was carried out on a Varian Capillary column, CP-WAX 58 (FFAP) CB $(25 \mathrm{~m}$ length $\times 0.32 \mathrm{~mm}$ internal diameter $\times 0.2 \mu \mathrm{m}$ film thickness, Varian). The injector volume was $2 \mathrm{~mL}$ and the injector temperature was maintained at $250^{\circ} \mathrm{C}$. Helium was employed as the carrier gas, at a flow rate of $1 \mathrm{~mL} \mathrm{~min}^{-1}$. The temperature program was as follows: $50^{\circ} \mathrm{C}(20 \mathrm{~s})$ to $110^{\circ} \mathrm{C}(20 \mathrm{~s})$ at a rate of $2^{\circ} \mathrm{C} \mathrm{min}{ }^{-1}$; from $110^{\circ} \mathrm{C}$ to $200^{\circ} \mathrm{C}(20 \mathrm{~s})$ at a rate of $20^{\circ} \mathrm{C} \mathrm{min}{ }^{-1}$. The MS-detector was operated in the scan mode in the range of $40-150 \mathrm{mz}^{-1}$ at a temperature of $210^{\circ} \mathrm{C}$. Identification of VFAs was achieved by matching chromatographic retention times and spectra of standard compounds (acetic-, butyric- and propionic-acids). Calibration curves of standard VFAs were constructed and used for relative concentration of VFAs in effluent headspace samples, expressed as $\mathrm{mg} \mathrm{L}^{-1}$.

2.3. Specific Methanogenic Activity (SMA) Testing. Biomass samples were screened for metabolic capability using specific methanogenic activity (SMA) tests. These were performed using the pressure transducer technique $[12,13]$, in which propionate $(30 \mathrm{mM})$, butyrate $(15 \mathrm{mM})$, and ethanol $(30 \mathrm{mM})$ were used as substrates to assay indirect methanogenesis. All assays contained $2-5 \mathrm{~g}$ volatile suspended solids (VSS) $\mathrm{L}^{-1}$ and were performed in triplicate at the bioreactor operational temperature ( $\mathrm{R} 1$ and $\mathrm{R} 237^{\circ} \mathrm{C}$; R3 and $\mathrm{R} 415^{\circ} \mathrm{C}$ ). Vials without any substrate were used as controls.

2.4. Extraction of Genomic DNA. Total genomic DNA was extracted in duplicate from the four biomass samples using an automated nucleic acid extractor (Magtration 12GC, PSS Co., Chiba, Japan). Granular biomass was finely crushed using a mortar and pestle, and re-suspended in $1 \mathrm{x}$ phosphate buffered saline to a ratio of $1: 4 \mathrm{w} / \mathrm{v}$. A $100 \mu \mathrm{L}$ aliquot of the biomass suspension was loaded per extraction. Extracted DNA was eluted in $100 \mu \mathrm{L}$ Tris- $\mathrm{HCl}$ buffer $(\mathrm{pH}$ 8.0) and stored at $-20^{\circ} \mathrm{C}$.

2.5. Clone Library Analysis of $16 S$ rRNA Genes. Bacterial clone libraries were constructed from the extracted genomic DNA; 16S rRNA genes were PCR-amplified using forward primer 27F (5'-AGA GTT TGA TCC TGG CTC AG-3'; [14]) and reverse primer 1392R (5' ACG GGC GGT GTG TRC-3'; [15]). Reaction mixtures $(50 \mu \mathrm{L})$ contained $1.5 \mathrm{mM}$

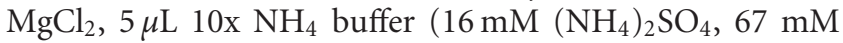
Tris- $\mathrm{HCl}\left(\mathrm{pH} 8.8\right.$ at $\left.25^{\circ} \mathrm{C}\right), 0.01 \%$ Tween-20), $0.2 \mathrm{mM}$ each dNTP (dATP, dCTP, dGTP, dTTP), 12.5 pmol of each primer, $2 \mu \mathrm{L}$ template DNA, and $1 \mathrm{U}$ Taq DNA polymerase. 
The PCR reactions were carried out using a touchdown PCR under the following conditions: initial denaturation at $95^{\circ} \mathrm{C}$ for $10 \mathrm{mins}$, followed by 10 cycles of $95^{\circ} \mathrm{C}$ for $60 \mathrm{~s}$, annealing at $63^{\circ} \mathrm{C}$ for $60 \mathrm{~s}$, and extension at $72^{\circ} \mathrm{C}$ for $120 \mathrm{~s}$, where the annealing temperature was decreased by $1{ }^{\circ} \mathrm{C}$ per cycle; followed by 20 cycles of denaturation at $95^{\circ} \mathrm{C}$ for $60 \mathrm{~s}$, annealing at $52^{\circ} \mathrm{C}$ for $60 \mathrm{~s}$, and extension at $72^{\circ} \mathrm{C}$ for $120 \mathrm{~s}$, followed by a final $10 \mathrm{~min}$ extension at $72^{\circ} \mathrm{C}$. Controls containing no DNA were also employed to identify amplification of contaminants, and none was detected. PCR products were ligated into the plasmid vector PCR 2.1-TOPO (Invitrogen) and the hybrid vectors were used to transform Escherichia coli TOP 10 competent cells, following the manufacturer's instructions. Transformants were screened using Luria-Bertani (LB) agar plates containing $50 \mu \mathrm{g} \mathrm{m}^{-1}$ kanamycin. Clone libraries were constructed by growing 96 randomly selected colonies derived from each sample at $37^{\circ} \mathrm{C}$ overnight in $200 \mu \mathrm{L}$ LB broth medium containing $50 \mu \mathrm{g} \mathrm{mL}^{-1}$ kanamycin in a 96-well plate.

2.6. Amplified rDNA Restriction Analysis (ARDRA). Ninetysix clones from each library were screened to determine if they contained the appropriately sized insert. Vectorspecific M13 forward and reverse primers were used at a concentration of $12.5 \mathrm{pmol}$, with the other PCR reagents as described previously. PCR conditions were: denaturation at $95^{\circ} \mathrm{C}$ for $10 \mathrm{~min} ; 30$ cycles of: $95^{\circ} \mathrm{C}$ for $60 \mathrm{~s}, 55^{\circ} \mathrm{C}$ for $60 \mathrm{~s}$, $72^{\circ} \mathrm{C}$ for $60 \mathrm{~s}$; followed by a final extension at $72^{\circ} \mathrm{C}$ for 10 minutes. Five $\mu \mathrm{L}$ of the resulting PCR products were digested with $0.8 \mu \mathrm{L}$ of the restriction endonuclease $\mathrm{HaeIII}$ at $37^{\circ} \mathrm{C}$ for 12-16 hours. The resulting DNA fragments were resolved by electrophoresis on 3.5\% (w/v) high resolution agarose and banding patterns were grouped into operational taxonomic units (OTUs).

2.7. Partial $16 S$ rDNA Sequencing, Phylogenetic, and Statistical Analysis. Inserts from clones representing the 52 OTU's identified were sequenced on a Licor gel sequencer using vector specific M13 primers (MWG Biotech, Germany). Sequences from this study were aligned with 16S rRNA gene sequences retrieved from BLASTn and the RDP using Clustal X [16], and the phylogenetic inference package Paup* 4.0b8 was used for all phylogenetic analysis [17]. The resulting partial 16S rRNA gene sequences were deposited in the GenBank database under the accession numbers HM749844-HM749879. The Simpson index of diversity (1 $D$ ) was calculated using the Primer6 software in order to compare the bacterial diversity of the four biomass samples as revealed by clone library analysis, using the algorithm $(D=\Sigma(n(n-1) / N(N-1))$, where $n$ is the number of individuals belonging to a species in any given sample and $N$ is the total number of individuals present in any given sample [18]. A Simpson's diversity index close to 1 means that the sample is highly diverse [18].

2.8. Denaturing Gradient Gel Electrophoresis (DGGE). DGGE analysis of bacterial $16 \mathrm{~S}$ rRNA genes extracted from the four samples was carried as follows: initial PCR amplification used the primers $341 \mathrm{~F}$ ( $5^{\prime}$-CCT ACG GGA GGC AGC AG-3'
[19]) and 517R (5'-ATT ACC GCG GCT GCT GG-3' [19]), with a 40-base pair GC clamp attached to the 5 ' terminus of the forward primer.

The touchdown PCR program consisted of an initial denaturation at $94^{\circ} \mathrm{C}$ for $120 \mathrm{~s}$; followed by 10 cycles of $94^{\circ} \mathrm{C}$ for $30 \mathrm{~s}$, annealing at $65^{\circ} \mathrm{C}$ for $30 \mathrm{~s}$, and extension at $72^{\circ} \mathrm{C}$ for $30 \mathrm{~s}$, where the annealing temperature was decreased by $1^{\circ} \mathrm{C}$ per cycle; followed by 20 cycles of denaturation at $95^{\circ} \mathrm{C}$ for $30 \mathrm{~s}$, annealing at $55^{\circ} \mathrm{C}$ for $30 \mathrm{~s}$ and extension at $72^{\circ} \mathrm{C}$ for $30 \mathrm{~s}$, followed by a final $10 \mathrm{~min}$ extension at $72^{\circ} \mathrm{C}$. A $40 \mu \mathrm{L}$ aliquot of GC-clamped PCR product was loaded onto a $10 \%(\mathrm{w} / \mathrm{v})$ polyacrylamide gel containing a denaturing gradient of $30-70 \%$ (where $100 \%$ denaturant contained $7 \mathrm{M}$ urea, $40 \%$ formamide) and ran at $60^{\circ} \mathrm{C}$ and $70 \mathrm{~V}$ for $16 \mathrm{~h}$ in a D-Code system (BioRad, Hercules, CA). The DGGE gels were ethidium bromide stained and photographed under UV trans-illumination. Seventeen bands were selected for further investigation by sequencing and phylogenetic analysis. Ten of these selected bands were present in all samples and were not affected by either temperature or TCE. Six bands were present only at $15^{\circ} \mathrm{C}$ (R3 and R4), while one band was present only at $37^{\circ} \mathrm{C}(\mathrm{R} 1$ and $\mathrm{R} 2)$, with both conditions indicating a temperature-dependent response of the microbial community. Selected bands were excised from the gel using a sterile scalpel blade, resuspended in $200 \mu \mathrm{L}$ of sterile water, and stored at room temperature for three hours to elute DNA from the gel for use as a PCR template. PCR reactions were performed under the conditions described above and the resulting PCR products were cloned using TOPO TA (Invitrogen). Plasmids from five randomly selected clones per reaction were extracted and $2 \mu \mathrm{L}$ of plasmid DNA was employed as a template for PCR using the same primers and conditions as described previously. For confirmatory purpose, the products of PCR from plasmid DNA were electrophoresed on a DGGE gel in parallel with the corresponding original PCR product. Plasmids that produced bands that underwent denaturation at the same gradient concentration as the original sample, and thereby migrated the same distance through the gel, were selected and sequenced (MWG Biotech, Germany).

Sequences from this study were aligned with $16 \mathrm{~S}$ rRNA gene sequences retrieved from BLASTn and the RDP using Clustal X [16], and the phylogenetic inference package Paup* 4.0b8 was used for all phylogenetic analysis [17]. The resulting partial 16S rRNA gene sequences were deposited in the GenBank database under the accession numbers HM749788-HM749804.

2.9. Statistical Analysis of DGGE Data. DGGE gels were analysed by creating binary matrices, where-by the presence or absence of bands in each sample were denoted with the numeric values " 1 " or " 0 ", respectively. These matrices were used to calculated unweighted pair-group methods using arithmetic averages (UPGMA) similarity dendrograms using the PC-ORD 5.0 statistical package [20].

2.10. Two-Dimensional Gel Electrophoresis (2-DGE). Proteins were extracted in duplicate from $50 \mathrm{~mL}$ of each granular sludge sample by sonication and subsequently separated 
TABLE 1: Specific Methanogenic Activity (SMA) of biomass sampled from R1 to R4 on day 235 of bioreactor trial, when influent TCE concentrations of R1 and R3 were $60 \mathrm{mg} \mathrm{L}^{-1}$ [9] Values shown are expressed as $\mathrm{mL} \mathrm{CH}_{4} \mathrm{gVSS}^{-1}$ day $^{-1}$ and are means of triplicates with std. errors (std. deviation $/ \sqrt{n}, n=3$ ) given in parentheses.

\begin{tabular}{lcccc}
\hline Temperature & Biomass & Propionate & Butyrate & Ethanol \\
\hline \multirow{2}{*}{$37^{\circ} \mathrm{C}$} & R1 (TCE) & $123(5)$ & $124(3)$ & $160(11)$ \\
& R2 (Control) & $222(2)$ & $160(33)$ & $210(28)$ \\
\hline \multirow{2}{*}{$15^{\circ} \mathrm{C}$} & R3 (TCE) & $82(5)$ & $14(1)$ & $51(5)$ \\
& R4 (Control) & $164(1)$ & $23(2)$ & $48(11)$ \\
\hline
\end{tabular}

by 2-DGE $[21,22]$. Briefly, the first dimension consisted of isoelectric focusing (IEF) using $7 \mathrm{~cm}$ IPG strips with linear $\mathrm{pH}$ gradients ( $\mathrm{pH} 4$ to 7; Amersham). The second dimension polyacrylamide $(12 \% \mathrm{w} / \mathrm{v})$ gels were run in pairs along with molecular weight markers with a range of $10-225 \mathrm{kDa}$ (Broad Range Protein Molecular Markers, Promega). Gels were stained overnight in GelCode 135 Blue staining reagent (Pierce) and then destained in deionised, distilled water for several hours. Twenty four gels were run corresponding to two duplicate independent extractions and three technical replicates of four samples. Gel images were processed and analysed with PDQuest-Advanced software, version 8.0.1 (BioRad). Spot counts were obtained using the spot detection wizard enabling the Gaussian model option and data normalisation was performed using the Local Regression Model, as recommended by the manufacturer. Ratios of spot intensities were determined in the presence and absence of TCE at both $37^{\circ} \mathrm{C}$ and $15^{\circ} \mathrm{C}$. Protein expression ratios greater than two-fold were considered significant. Proteins deemed of interest were excised from the gels and identified using nanoflow liquid chromatographyelectrospray ionization tandem mass spectrometry (nLCESI-MS/MS), as previously described [21, 22].The MS/MS data were analysed using the Mascot 2.2 search engine (Matrix Science, London, UK) against the NCBInr database (04 March 2010, 10,530,540 sequences) with no species restriction. Positive protein identification was based on two criteria: a Mascot Mowse score of >52 (95\% confidence level) and a minimum detection of two peptides per protein.

\section{Results}

3.1. Specific Methanogenic Activity. At R1 and R3 influent TCE concentrations of $60 \mathrm{mg} \mathrm{L}^{-1}$, the SMA against propionate, butyrate, and ethanol was generally lower for both TCE-supplemented bioreactors (R1 and R3) than their corresponding controls (R2 and R4; Table 1). For each of the three substrates tested, the activity of the TCEsupplemented bioreactors was higher at $37^{\circ} \mathrm{C}(\mathrm{R} 1)$ than at $15^{\circ} \mathrm{C}$ (R3; Table 1 ), with the same trend observed for biomass originating from the control bioreactors, with activity of R2 $\left(37^{\circ} \mathrm{C}\right)$ higher than that of $\mathrm{R} 4\left(15^{\circ} \mathrm{C}\right)$ for all three substrates utilised in this assay (Table 1).

3.2. Clone Library Analysis of $16 S$ rRNA Genes. ARDRA was carried out on a total of 354 clones, and several temperaturerelated, but apparently TCE-independent, changes in the bacterial community structure were observed (Figure 1). For example, although clones related to the phylum Proteobacteria were dominant in all bioreactors, the proportion of Proteobacteria-like clones was higher in both R1 and R2 $\left(37^{\circ} \mathrm{C}\right.$, with and without TCE, resp.) than in R3 and R4 $\left(15^{\circ} \mathrm{C}\right.$, with and without TCE, resp.), while the opposite was true of Bacteroidetes-, Chloroflexi-, and Firmicutes-like clones (Figure 1). The $15^{\circ} \mathrm{C}$ biomass samples showed higher species diversity than at $37^{\circ} \mathrm{C}$, and Simpson's diversity indices were: $\mathrm{R} 1\left(37^{\circ} \mathrm{C}\right.$ TCE) 0.7032 ; R2 ( $37^{\circ} \mathrm{C}$ control) 0.6384 ; R3 $\left(15^{\circ} \mathrm{C}\right.$ TCE) 0.8459 ; $\mathrm{R} 4\left(15^{\circ} \mathrm{C}\right.$ control $) 0.8462$.

3.3. DGGE. UPGMA analysis of PCR-DGGE data demonstrated that the bacterial community of the biomass statistically clustered by bioreactor operational temperature, with the $37^{\circ} \mathrm{C}$ bacterial communities (R1 and R2) demonstrating $>80 \%$ similarity, and the $15^{\circ} \mathrm{C}$ bioreactors ( $\mathrm{R} 3$ and R4) demonstrating $>90 \%$ similarity, irrespective of TCE exposure (Figure 2). Furthermore, the greatest difference in the bacterial community structure of these samples was observed between the $37^{\circ} \mathrm{C}$ and $15^{\circ} \mathrm{C}$ bioreactor clusters, which established temperature as a stronger driving force in bacterial community diversity than TCE (Figure 2).

Phylogenetic analysis of the seventeen DNA fragments excised from the DGGE gel allowed the identification of organisms within the bacterial community (Figure 3). Of these seventeen bands, ten were present in all samples, of which nine were identified as being closely associated with: Pseudomonas (B1), Syntrophomonas (B2), Geobacter (B3 and B11), Desulfovibrio (B9), Syntrophaceae (B10), Myxococcales (B12), Deltaproteobacteria (B13), and Firmicutes (B14), while B7 did not group with any classified bacterial phylum (Figure 3).

Six bands were only detected at $15^{\circ} \mathrm{C}(\mathrm{R} 3$ and $\mathrm{R} 4)$ and were related to: Planctomycetes (B4), Bacteroidetes (B5), Chloroflexi (B6 and B15), Deltaproteobacteria (B16), and Spirochaetes (B17); while only B8 was present exclusively at $37^{\circ} \mathrm{C}(\mathrm{R} 1$ and $\mathrm{R} 2)$ and was identified as a Thermotogaelike species (Figure 3). Overall, six of the seventeen bands analysed were phylogenetically affiliated with Proteobacteria, (B3, B10, B11, B12, B13, B16) establishing it as the most dominant phylum (Figure 3). No bands were observed on DGGE gels that were differentially detected due to the presence or absence of TCE.

3.4. Metaproteomics. Ninety-three distinct spots were excised and sequenced for protein identification based on protein expression ratios. Spots were selected so that proteins that were constitutively expressed, induced or repressed in the presence of TCE were all included for analysis. Of these, $46 \%$ were positively identified using nLC-ESI-MS/MS. A number of proteins were found to have migrated as several distinct spots, resulting in the positive identification of 27 unique proteins (Table 2).

Twelve proteins were associated with bacterial species, ten of which were members of the phylum Proteobacteria, with the Actinobacteria and Firmicutes each represented by one protein (Table 2). The functions of proteins originating from bacterial species were highly varied. Proteins associated with 


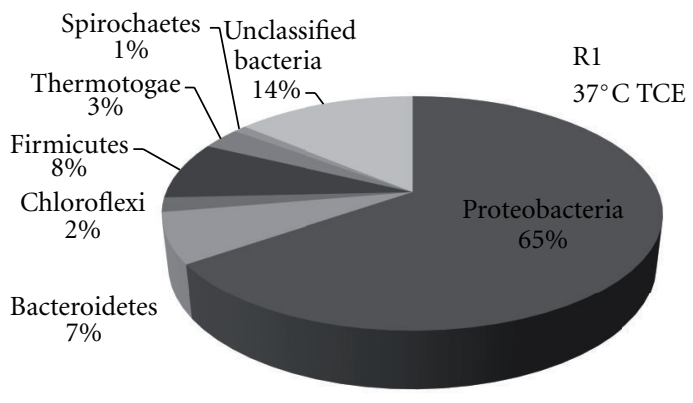

(a)

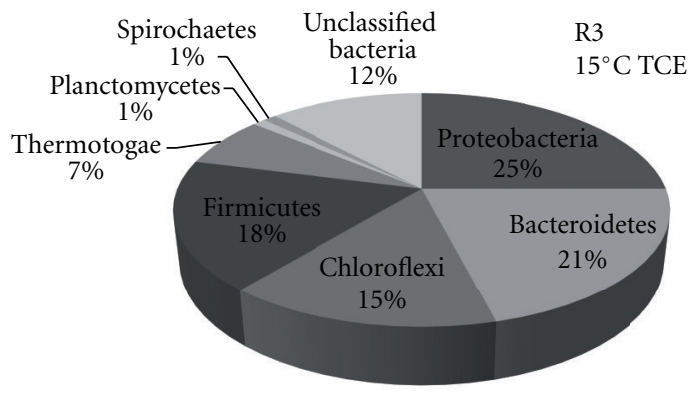

(c)

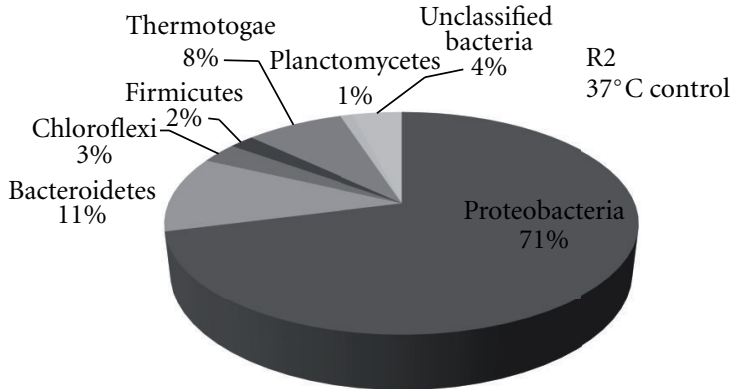

(b)

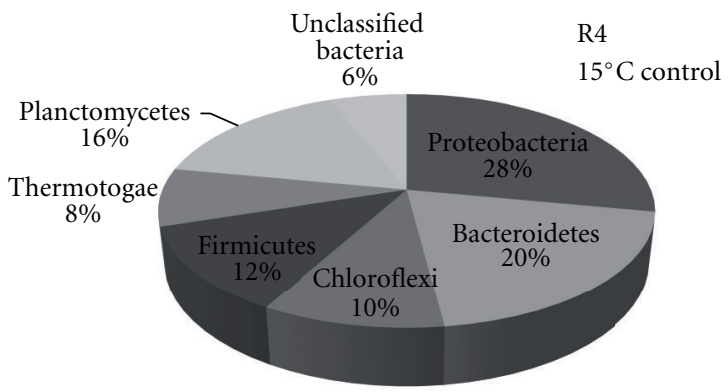

(d)

Figure 1: Diversity of bacterial clones obtained from $16 \mathrm{~S}$ rRNA gene clone libraries. R1: $37^{\circ} \mathrm{C}$ TCE-supplemented; $\mathrm{R} 2: 37^{\circ} \mathrm{C}$ control; R3: $15^{\circ} \mathrm{C}$ TCE-supplemented; R4: $15^{\circ} \mathrm{C}$ control.

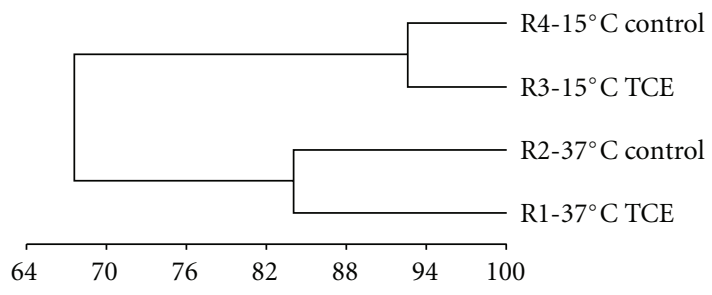

Figure 2: Bacterial UPGMA cluster analysis of $16 \mathrm{~S}$ rDNA fragments generated from DGGE banding profiles. Percent similarity calculated by ( $1-$ Sorensons (Bray-Curtis) distance measurement) * 100. R1: $37^{\circ} \mathrm{C}$ TCE-supplemented; R2: $37^{\circ} \mathrm{C}$ control; R3: $15^{\circ} \mathrm{C}$ TCE-supplemented; R4: $15^{\circ} \mathrm{C}$ control.

the metabolism of components of the influent wastewater, namely acetate (phosphate acetyltransferase) and ethanol (alcohol dehydrogenase), were identified in all samples, and were affiliated with the Proteobacteria (Table 2).

Five proteins were identified that could be involved in the degradation of glyoxylate (Table 2). Glyceraldehyde-3phosphate dehydrogenase, an enzyme of the glycolytic pathway, was detected in all samples (Table 2), indicating that the glycolytic pathway appears to be active under all of the conditions investigated. In addition, there is evidence of activity of the methyl-malonyl pathway, as methyl malonyl-CoA mutase was detected in all samples, and was upregulated ca. 24fold in the presence of TCE at $37^{\circ} \mathrm{C}$ (Table 2). SuccinylCoA synthetase, associated with the production of succinyl$\mathrm{CoA}$, which is required for the methyl malonyl pathway, was identified in both $37^{\circ} \mathrm{C}$ samples, but not at $15^{\circ} \mathrm{C}$ (Table 2). Malate dehydrogenase, a protein of the glyoxylate cycle that converts malate to oxaloacetate, was also identified in all samples, but was downregulated 3 -fold in the presence of TCE at $15^{\circ} \mathrm{C}$ (Table 2). Oxaloacetate, in turn, can be converted to aspartate, which can lead to the production of $\mathrm{L}$-homocysteine via the formation of $\mathrm{O}$-acetyl-L-homoserine by $\mathrm{O}$-acetylserine sulfhydrylase, an enzyme which was detected in all samples and was found to be upregulated in the presence of TCE at both temperatures (Table 2). O-acetylserine sulfhydrylase was assigned to Geobacter sp., known to be involved in TCE dechlorination [24].

The remaining nine proteins were assigned to archaeal species belonging to the orders Methanomicrobiales and Methanobacteriales, and to the family Methanosaeta (Table 2). Unsurprisingly, methanogenesis dominated the suggestedfunction of proteins originating from the archaea, with proteins involved in the production of methane from acetate (Acetyl-CoA decarbonylase) and $\mathrm{CO}_{2}$ (coenzyme F420 dependent N5, N10 methylenetetrahydromethanopterin reductase) identified in all samples (Table 2).

In addition, several house-keeping proteins were identified, and included those involved in ATP synthesis and proteolysis, while acetate-CoA ligase was upregulated in the presence of TCE at both temperatures, which would result in increased production of acetyl-CoA (Table 2). Finally, a hypothetical protein of unknown function was detected at $37^{\circ} \mathrm{C}$, and affiliated with Methanospirillum sp. (Table 2).

\section{Discussion}

Several results indicated a negative response of the bacterial community to the presence of TCE, particularly at the maximum applied concentration of $60 \mathrm{mg} \mathrm{L}^{-1}$. For example, the accumulation of measured VFA, particularly propionic 


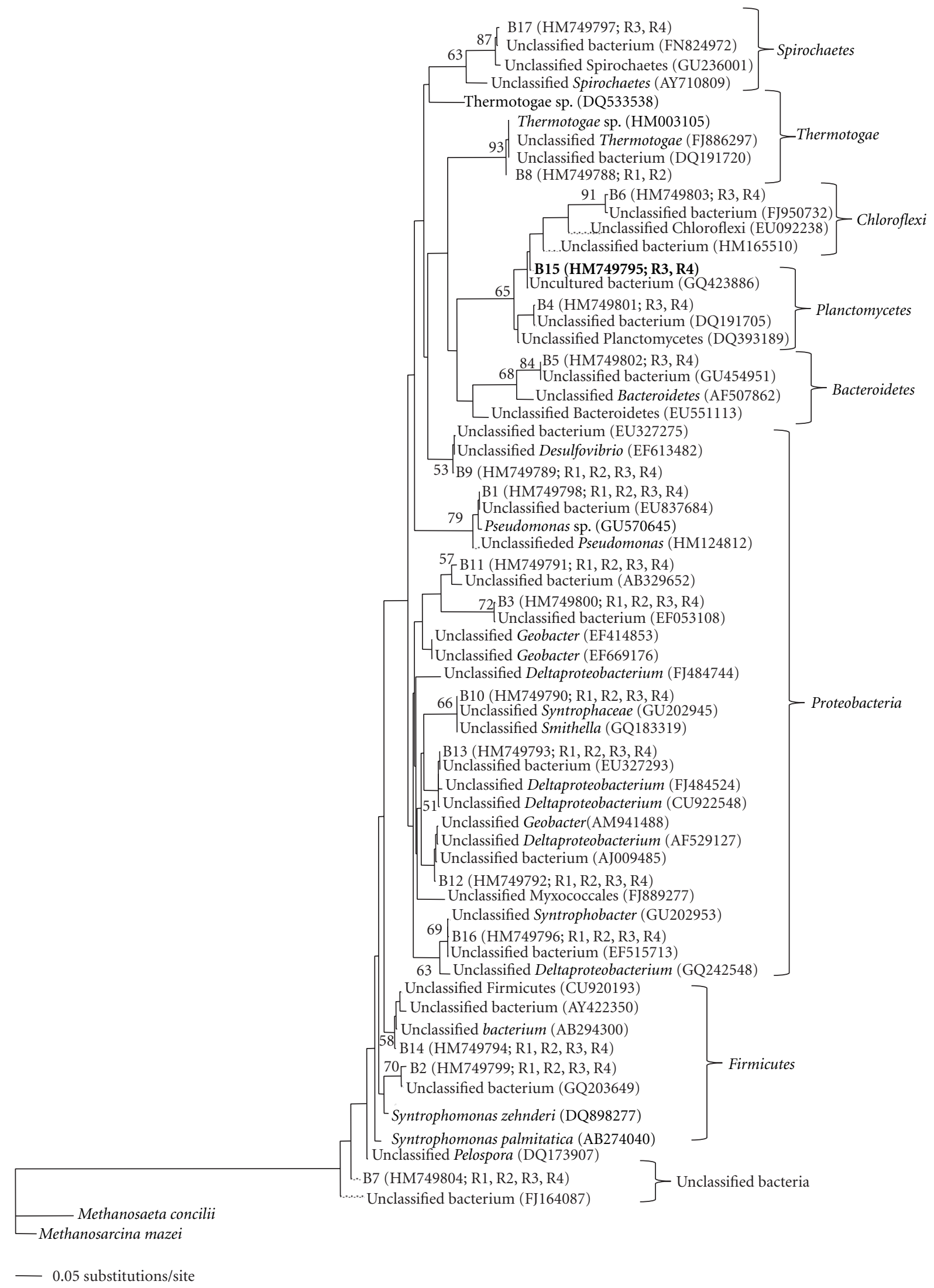

FIGURE 3: Phylogeny of bacterial sequences obtained by DGGE from R1-R4 biomass, calculated using the Kimura-2 algorithm and the neighbour-joining method [23]. Bootstrap replicates (total 100 replicate samplings) supporting the branching order are shown at relevant nodes. Accession numbers and the bioreactor biomass containing the respective bands are given in parenthesis. R1: $37^{\circ} \mathrm{C}$ TCE-supplemented; R2: $37^{\circ} \mathrm{C}$ control; R3: $15^{\circ} \mathrm{C}$ TCE-supplemented; R4: $15^{\circ} \mathrm{C}$ control. 


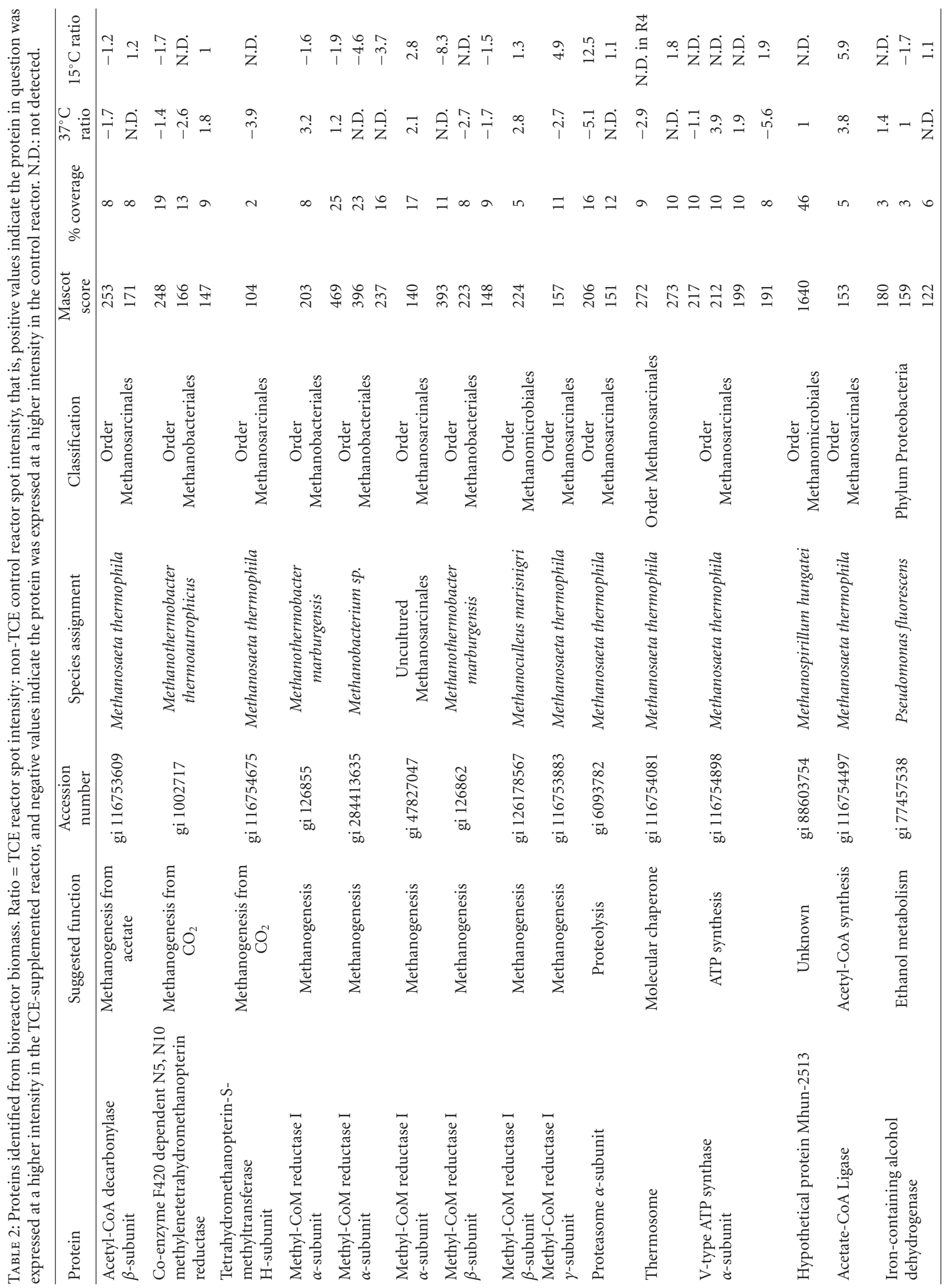




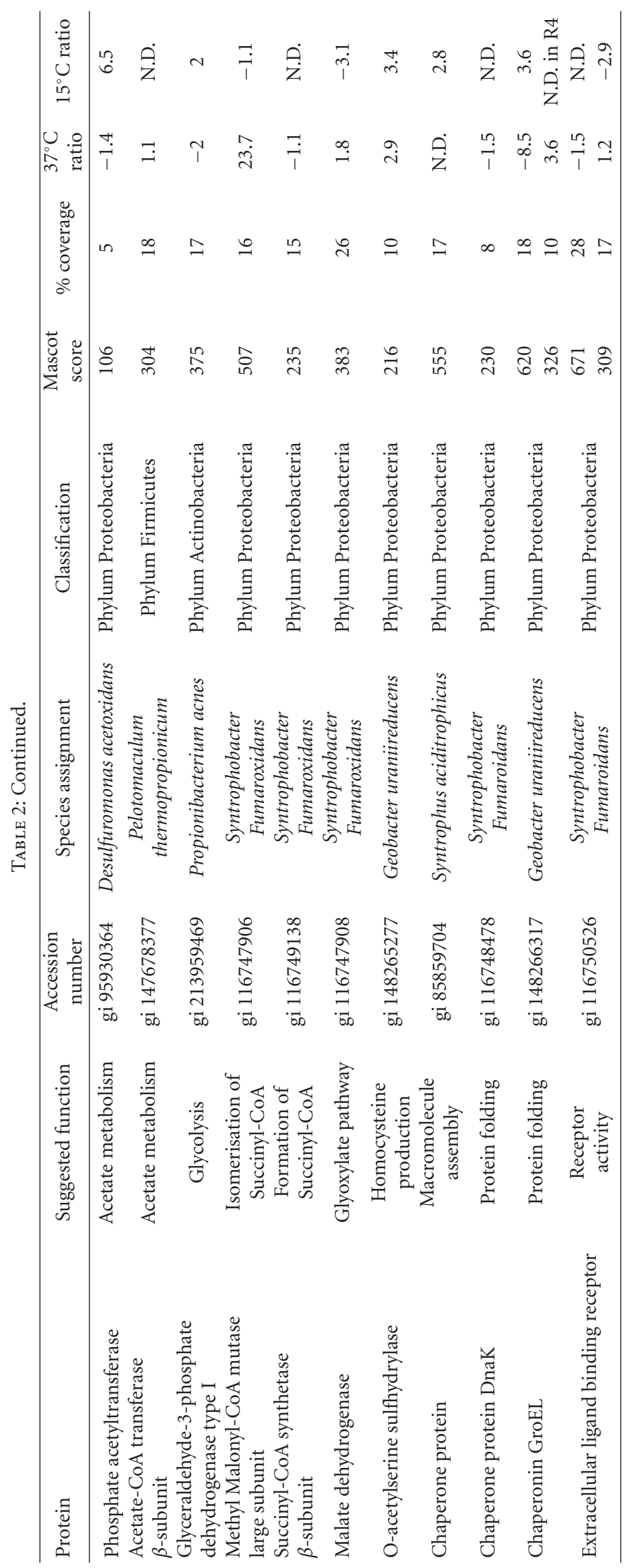




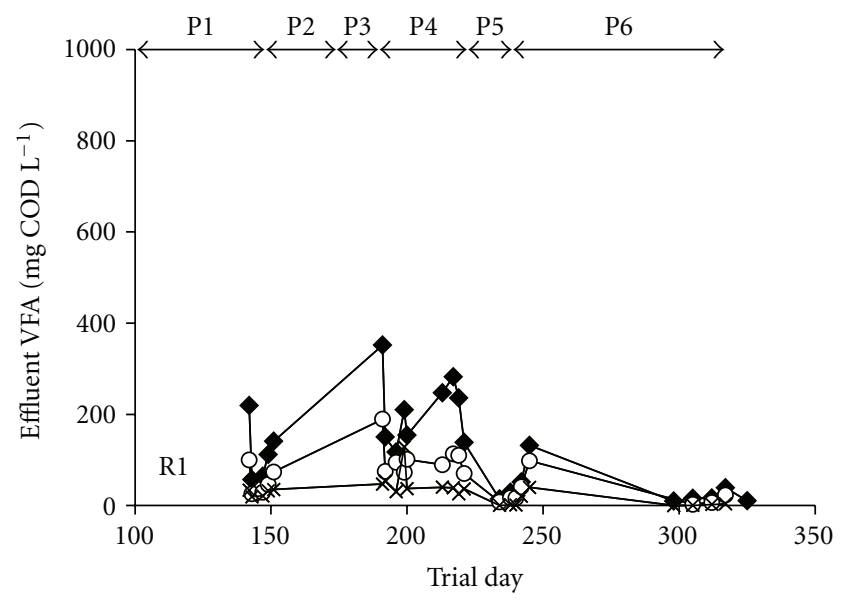

(a)

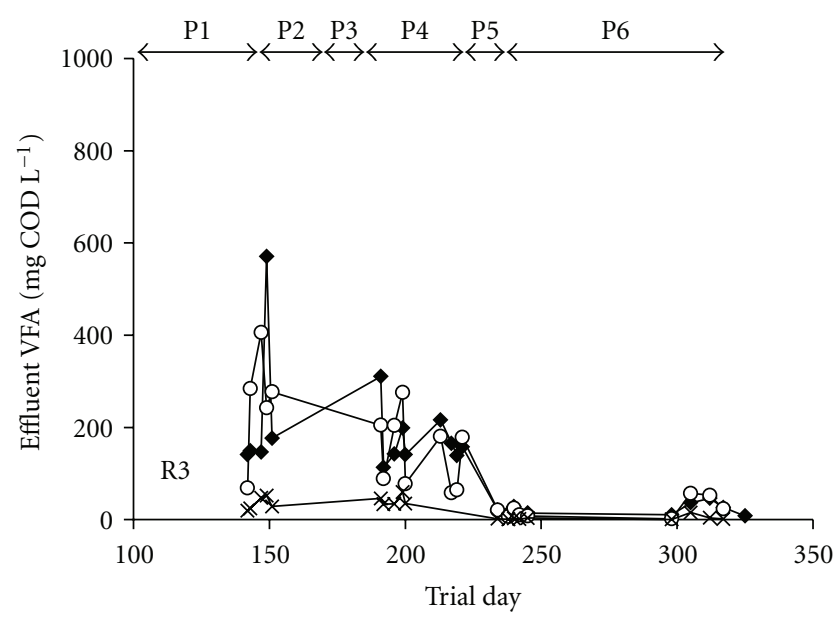

(c)

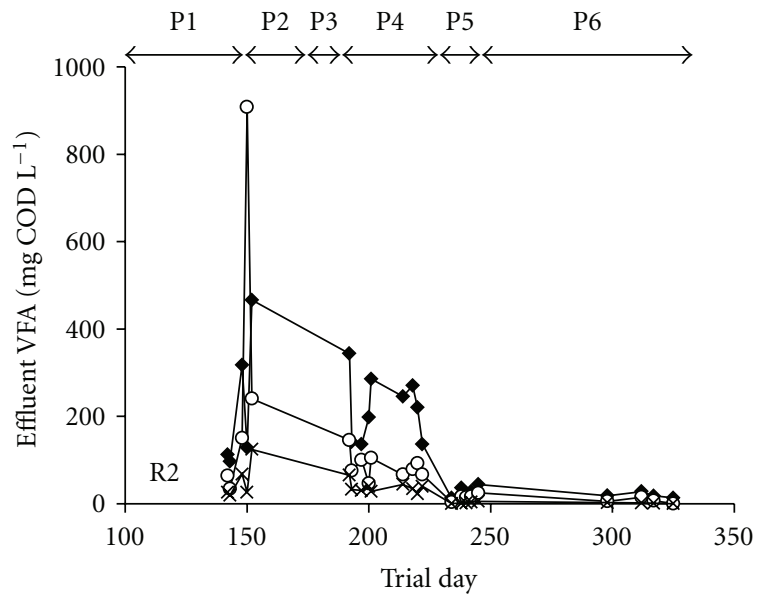

(b)

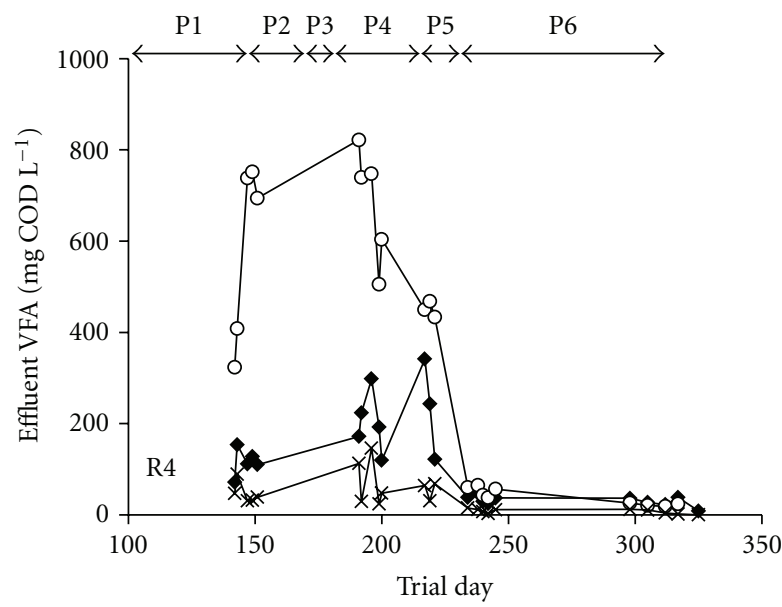

(d)

Figure 4: Effluent VFA concentrations of R1-R4: acetic acid ( $\$$ ); propionic acid $(\bigcirc)$; butyric acid (-x-). R1: $37^{\circ} \mathrm{C}$ TCE-supplemented; R2: $37^{\circ} \mathrm{C}$ control; $\mathrm{R} 3: 15^{\circ} \mathrm{C}$ TCE-supplemented; R4: $15^{\circ} \mathrm{C}$ control.

acid, was observed during process perturbations following the initial TCE addition and subsequent increases in TCE concentration (Figure 4). Also, SMA assays using indirect methanogenic substrates indicated that on day 235, the activities of propionate, butyrate, and ethanol utilisers were generally lower in the TCE-supplemented bioreactors than in their control counterparts (Table 1). However, analysis of the bacterial community during this study did not reveal any significant changes in the community structure that could be strongly attributed to the process failure observed in both $\mathrm{R} 1\left(37^{\circ} \mathrm{C}\right)$ and $\mathrm{R} 3\left(15^{\circ} \mathrm{C}\right)$ at influent TCE concentrations of $60 \mathrm{mg} \mathrm{L}^{-1}$ [9]. As was the case of with the archaeal population [9], it would appear that the bacterial community was not structurally affected by the addition of TCE; however the reduced activity of the syntrophic populations may have contributed to process failure.

By employing 16S rRNA gene analysis (DGGE and clone libraries) this study aimed to target the bacterial community structure and identify changes that may have been associated with temperature-and/or TCE-induced process failure. Additionally, metaproteomic analysis of the overall microbial community was carried out in an attempt to identify proteins associated with ongoing functions in the bioreactors, including the reductive dechlorination of TCE.

The high levels of Proteobacteria-like species observed by DGGE and 16S rRNA gene clone libraries in all samples was in keeping with previous studies, which reported that Proteobacteria are commonly amongst the dominant phyla in anaerobic bioreactors $[25,26]$. Analysis of the metaproteome confirmed the metabolic activity of Proteobacteria in all samples (Table 2), substantiating the importance of this phylum in the process of anaerobic digestion. Correspondingly, several key Proteobacteria species were identified by one or more of these techniques. For example, propionate-oxidising Syntrophobacter fumaroxidans were present in all samples, detected by both bacterial clone library (Figure 1) and DGGE analysis (Figure 3), and were associated with three of the proteins involved in the metabolic pathways outlined in Figure 5. One of these proteins, methyl malonyl CoA mutase, which is involved in the metabolism of propionate 


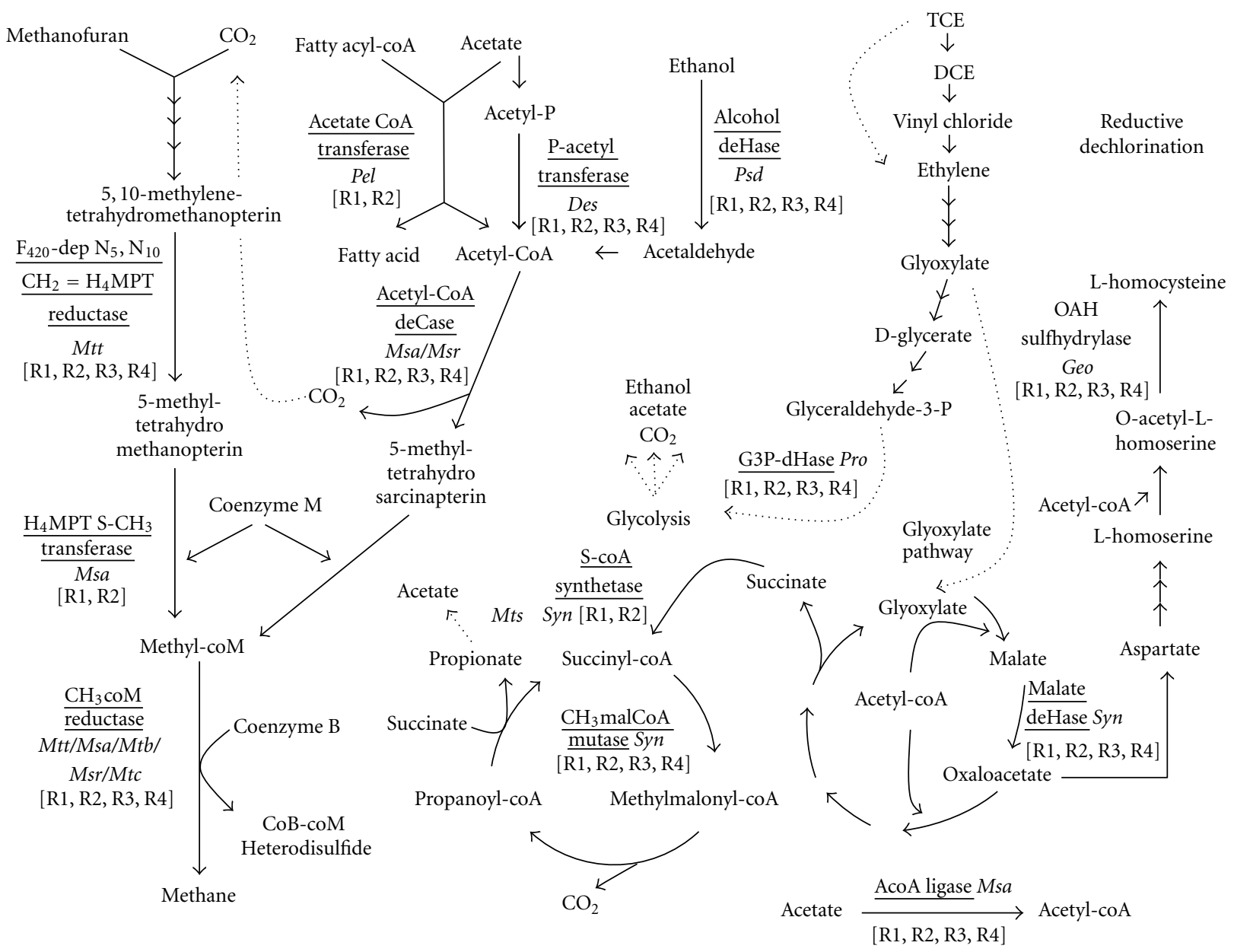

FIGURE 5: Proposed metabolic pathway for the degradation of VFA and TCE inferred from the metaproteomic data. Enzymes identified in this study are underlined. Species abbreviations are as follows: Mtt Methanothermobacter sp.; Msa Methanosaeta sp.; Mtb Methanobacterium sp.; Msr Methanosarcinales sp.; Mtc Methanoculleus sp.; Pel Pelotomaculum sp.; Des Desulfuromonas sp.; Psd Pseudomonas sp.; Syn Syntrophobacter sp.; Pro Propionibacterium sp.; Geo Geobacter sp. Enzymes were identified from the bioreactors indicated within square brackets, where R1: $37^{\circ} \mathrm{C}$ TCE-supplemented; R2: $37^{\circ} \mathrm{C}$ control; R3: $15^{\circ} \mathrm{C}$ TCE-supplemented; $\mathrm{R} 4: 15^{\circ} \mathrm{C}$ control.

(Figure 5), was strongly induced in the presence of TCE at $37^{\circ} \mathrm{C}$ (Table 2), although SMA assays indicated a lower activity of propionate mediated methanogenesis in the presence of TCE (Table 1). It is possible that production of methyl malonyl CoA mutase increased in response to this metabolic bottleneck, and facilitated the stable production of $\mathrm{CH}_{4}$ at $37^{\circ} \mathrm{C}$. In addition, as oxidation of intermediate reduced organic compounds such as propionate is energetically unfavourable, Syntrophobacter require growth in coculture with methanogens that utilise both hydrogen and formate, such as Methanospirillum hungatei, thereby maintaining low concentrations of these oxidation products and allowing energy gain by all organisms involved [27, 28]. qPCR analysis using a primer/probe set specific for the order Methanomicrobiales,to which the Methanospirillum belong, quantified $16 \mathrm{~S}$ rRNA gene numbers of $10^{7}-10^{9}$ copies [gVSS] $^{-1}$ on day 235 [9], while specifically, Methanospirillum hungatei was detected by analysis of the metaproteome, and associated with a protein of unknown function (Table 2).
Clones associated with several bacterial phyla were detected at low levels in various bioreactors, for example: Bacteroidetes- and Chloroflexi-like clones were identified in all biomass samples (R1-R4; Figure 1); Spirochaeteslike clones only accounted for $1 \%$ of the clones from R1 and R3 biomass and were not detected in either R2 or R4 (Figure 1); and Planctomycetes-like clones were detected in R2, R3 and R4 (Figure 1). The phyla Planctomycetes, Bacteroidetes,Chloroflexi, and Spirochaeteswere each represented by one DGGE band, which were detected in both $15^{\circ} \mathrm{C}$ bioreactors, but were not detected at $37^{\circ} \mathrm{C}(\mathrm{B} 4$, B5, B6 and B17, resp., Figure 3). It is possible that PCR amplification for DGGE was biased against the low levels of these phyla in the bioreactors, as the amplification of a more abundant template DNA fragment has been shown to suppress the amplification of a minor template [29]. These phyla have been classically identified within bioreactors, although the exact functions of Bacteroidetes, Chloroflexi, and Spirochaetes are as of yet unknown [30]. As no proteins 
affiliated with these phyla were identified in any sample (Table 2), the functions of these microbial groups in anaerobic bioreactors could not be determined from this study. The majority of the literature regarding the role of the phylum Planctomycetes in granular biomass focuses on the anaerobic ammonium oxidising (ANAMMOX) bacteria [31], which convert nitrate and ammonium directly to dinitrogen gas [32], although none of the known proteins associated with this process were identified in this study (Table 2).

Firmicutes-like species were detected by multiple analytical methods in all of the samples. For example, Peptococcaceae-like clones were detected in each clone library (Figure 1) while metaproteomics detected acetate-CoA transferase in both $37^{\circ} \mathrm{C}$ bioreactors (Table 2), which was associated with Pelotomaculum thermopropionicum, a thermophilic, syntrophic, propionate-oxidising bacterium of the Peptococcaceae family [33]. This species has been shown to grow in coculture with the hydrogenotrophic Methanothermobacter thermoautotrophicus [33], which was also found to be active in all biomass samples (Table 2). Furthermore, Syntrophomonas species within the Firmicutes phylum were represented by both clone library (Figure 1) and DGGE analysis (Figure 3 ) in all samples, and have previously been shown to grow syntrophically with Methanospirillum species, resulting in the formation of methane [34].

The order Desulfuromonadales, and specifically, Geobacter species, were detected in all samples (Figures 1 and 3), and have both been associated with the partial dechlorination of TCE to cis-1,2 DCE [24]. A protein associated with Geobacter sp., O-acetylserine sulfhydrylase, was upregulated in the presence of TCE, at both $37^{\circ} \mathrm{C}$ and $15^{\circ} \mathrm{C}$ (Table 2). Oacetylserine sulfhydrylase is involved in the production of L-homocysteine (Figure 5), which can be further converted to cysteine (involved in protein folding) or methionine (often found to interact with the lipid bilayer of membranespanning protein domains; [35]). It is possible then, that an increased production of $\mathrm{O}$-acetylserine sulfhydrylase might lead to an increased level of L-homocysteine as a response to the action of lipophilic TCE, which may associate with the cell membrane, resulting in inhibition of cell membrane ATPases [36]. Interestingly, although Geobacter species have been associated with TCE dechlorination [24] and have been detected in this study through both clone library (Figure 1) and DGGE analysis (Figure 3), the use of metaproteomics allowed a suggestion for a specific function for this group to be put forward.

No proteins specifically associated with the reductive dechlorination of TCE were identified by 2-DGE analysis of the metaproteome (Table 2). One hypothesis is that as the bioreactor influent contained a much higher concentration of VFA's than TCE, it is possible that the TCE concentration induced the production of sufficient enzymes for TCE dechlorination, but was insufficient for detection by 2-DGE. Although the dechlorination of TCE was not monitored during this trial, we have previously reported the successful dechlorination of TCE to DCE (>98\%) with a similar experimental design at $37^{\circ} \mathrm{C}$ and $15^{\circ} \mathrm{C}$ [37], and at temperatures as low as $7^{\circ} \mathrm{C}$ [38]. Similar difficulties associated with the detection of specific enzymes involved in bioremediation pathways have been encountered with regards to hydrocarbons [39] and chemical pollutants such as toluene [40]. The absence of a matched metagenomic dataset unquestionably hinders protein identification, for example, previous studies have shown that analysis of the metaproteome of activated sludge by 2-DGE resulted in the identification of 38 proteins [41], while implementation of the 2D-nano-LC method with a metagenomic dataset led to the identification of 5029 proteins [42].

Overall, both clone library and DGGE analysis of the bioreactor bacterial populations identified a divergence from the seed biomass that could be attributed more to temperature than TCE. Specifically, UPGMA analysis of DGGE band diversity revealed that the greatest change in bacterial community development occurred between the bioreactors operating at $37^{\circ} \mathrm{C}$ and at $15^{\circ} \mathrm{C}$ (Figure 2), while at both temperatures, TCE resulted in a change of $<5 \%$ between the TCE-exposed and the control biomass (Figure 2). This supports previous studies, which concluded that while analysis of bacterial population dynamics is important, it is not a reliable indicator of process events, as high levels of dynamism can be observed even during times of functional stability $[43,44]$.

\section{Conclusions}

The following conclusions can now be drawn: (1) changes in the metaproteome could be observed as a function of operational temperature and exposure to TCE; (2) according to DGGE UPGMA data, the major driver for bacterial community structure development in anaerobic bioreactors was temperature, with a limited response to the presence of TCE; (3) the detection of specific function associated proteins (such as TCE reductive dehalogenases) could have been improved by the availability of a metagenomic dataset to assist protein identification.

\section{Acknowledgments}

This work was supported by Enterprise Ireland, The Irish Environmental Protection Agency, and Science Foundation Ireland.

\section{References}

[1] G. Lettinga, "Anaerobic digestion and wastewater treatment systems," Antonie van Leeuwenhoek, International Journal of General and Molecular Microbiology, vol. 67, no. 1, pp. 3-28, 1995.

[2] D. Massé, Y. Gilbert, and E. Topp, "Pathogen removal in farmscale psychrophilic anaerobic digesters processing swine manure," Bioresource Technology, vol. 102, no. 2, pp. 641-646, 2011.

[3] R. M. McKeown, C. Scully, T. Mahony, G. Collins, and V. O'Flaherty, "Long-term (1243 days), low-temperature (4$15^{\circ} \mathrm{C}$ ), anaerobic biotreatment of acidified wastewaters: bioprocess performance and physiological characteristics," Water Research, vol. 43, no. 6, pp. 1611-1620, 2009.

[4] T. Amani, M. Nosrati, and T. R. Sreekrishnan, "Anaerobic digestion from the viewpoint of microbiological, chemical and 
operational aspects-a review," Environmental Reviews, vol. 18, pp. 255-278, 2010.

[5] A. M. Enright, G. Collins, and V. O'Flaherty, “Temporal microbial diversity changes in solvent-degrading anaerobic granular sludge from low-temperature $\left(15^{\circ} \mathrm{C}\right)$ wastewater treatment bioreactors," Systematic and Applied Microbiology, vol. 30, no. 6, pp. 471-482, 2007.

[6] K. Bialek, J. Kim, C. Lee, G. Collins, T. Mahony, and V. O'Flaherty, “Quantitative and qualitative analyses of methanogenic community development in high-rate anaerobic bioreactors," Water Research, vol. 45, no. 3, pp. 1298-1308, 2011.

[7] M. Tabatabaei, R. A. Rahim, N. Abdullah et al., "Importance of the methanogenic archaea populations in anaerobic wastewater treatments," Process Biochemistry, vol. 45, no. 8, pp. 1214 $1225,2010$.

[8] Y. Liu and W. B. Whitman, "Metabolic, phylogenetic, and ecological diversity of the methanogenic archaea," Annals of the New York Academy of Sciences, vol. 1125, pp. 171-189, 2008.

[9] A. Siggins, A. M. Enright, and V. O’Flaherty, "Methanogenic community development in anaerobic granular bioreactors treating trichloroethylene (TCE)-contaminated wastewater at $37^{\circ} \mathrm{C}$ and $15^{\circ} \mathrm{C}$," Water Research, vol. 45 , no. 8, pp. 2452-2462, 2011.

[10] USEPA United States National Toxicology Program, 12th Report on carcinogens, 2011, http://ntp.niehs.nih.gov/ntp/ roc/twelfth/profiles/Trichloroethylene.pdf.

[11] P. J. M. Middeldorp, M. L. G. C. Luijten, B. A. Van de Pas et al., "Anaerobic microbial reductive dehalogenation of chlorinated ethenes," Bioremediation Journal, vol. 3, no. 3, pp. 151-169, 1999.

[12] J. D. Coates, M. F. Coughlan, and E. Colleran, "Simple method for the measurement of the hydrogenotrophic methanogenic activity of anaerobic sludges," Journal of Microbiological Methods, vol. 26, no. 3, pp. 237-246, 1996.

[13] E. Colleran, F. Concannon, T. Golden et al., "Use of methanogenic activity tests to characterize anaerobic sludges, screen for anaerobic biodegradability and determine toxicity thresholds against individual anaerobic trophic," Water Science and Technology, vol. 25, no. 7, pp. 31-40, 1992.

[14] E. F. DeLong, "Archaea in coastal marine environments," Proceedings of the National Academy of Sciences of the United States of America, vol. 89, no. 12, pp. 5685-5689, 1992.

[15] D. J. Lane, B. Pace, and G. J. Olsen, "Rapid determination of $16 \mathrm{~S}$ ribosomal RNA sequences for phylogenetic analyses," Proceedings of the National Academy of Sciences of the United States of America, vol. 82, no. 20, pp. 6955-6959, 1985.

[16] J. D. Thompson, T. J. Gibson, F. Plewniak, F. Jeanmougin, and D. G. Higgins, "The CLUSTAL X windows interface: flexible strategies for multiple sequence alignment aided by quality analysis tools," Nucleic Acids Research, vol. 25, no. 24, pp. 4876-4882, 1997.

[17] D. L. Swofford, PAUP*. Phylogenetic Analysis Using Parsimony (*and Other Methods), Version 4, Sinauer Associates, Sunderland, Mass, USA, 2001.

[18] E. H. Simpson, "Measurement of diversity," Nature, vol. 163, no. 4148 , p. $688,1949$.

[19] G. Muyzer, E. C. De Waal, and A. G. Uitterlinden, "Profiling of complex microbial populations by denaturing gradient gel electrophoresis analysis of polymerase chain reactionamplified genes coding for 16S rRNA," Applied and Environmental Microbiology, vol. 59, no. 3, pp. 695-700, 1993.

[20] B. McCune and J. B. Grace, Analysis of Ecological Communities, MjM Software, Corvallis, Ore, USA, 2002.
[21] F. Abram, E. Gunnigle, and V. O’Flaherty, “Optimisation of protein extraction and 2-DE for metaproteomics of microbial communities from anaerobic wastewater treatment biofilms," Electrophoresis, vol. 30, no. 23, pp. 4149-4151, 2009.

[22] F. Abram, A. M. Enright, J. O’Reilly, C. H. Botting, G. Collins, and V. O'Flaherty, "A metaproteomic approach gives functional insights into anaerobic digestion," Journal of Applied Microbiology, vol. 110, no. 6, pp. 1550-1560, 2011.

[23] N. Saitou and M. Nei, "The neighbor-joining method: a new method for reconstructing phylogenetic trees," Molecular Biology and Evolution, vol. 4, no. 4, pp. 406-425, 1987.

[24] F. E. Löffler, Q. Sun, J. Li, and J. M. Tiedje, "16S rRNA genebased detection of tetrachloroethene-dechlorinating Desulfuromonas and Dehalococcoides species," Applied and Environmental Microbiology, vol. 66, no. 4, pp. 1369-1374, 2000.

[25] R. Chouari, D. Le Paslier, P. Daegelen, P. Ginestet, J. Weissenbach, and A. Sghir, "Novel predominant archaeal and bacterial groups revealed by molecular analysis of an anaerobic sludge digester," Environmental Microbiology, vol. 7, no. 8, pp. 1104-1115, 2005.

[26] J. J. Godon, E. Zumstein, P. Dabert, F. Habouzit, and R. Moletta, "Molecular microbial diversity of an anaerobic digestor as determined by small-subunit rDNA sequence analysis," Applied and Environmental Microbiology, vol. 63, no. 7, pp. 2802-2813, 1997.

[27] F. A. M. De Bok, M. L. G. C. Luijten, and A. J. M. Stams, "Biochemical evidence for formate transfer in syntrophic propionate-oxidizing cocultures of Syntrophobacter fumaroxidans and Methanospirillum hungatei," Applied and Environmental Microbiology, vol. 68, no. 9, pp. 4247-4252, 2002.

[28] X. Dong, C. M. Plugge, and A. J. M. Stams, "Anaerobic degradation of propionate by a mesophilic acetogenic bacterium in coculture and triculture with different methanogens," Applied and Environmental Microbiology, vol. 60, no. 8, pp. 2834-2838, 1994.

[29] S. Becker, P. Boger, R. Oehlmann, and A. Ernst, "PCR bias in ecological analysis: a case study for quantitative Taq nuclease assays in analyses of microbial communities," Applied and Environmental Microbiology, vol. 66, no. 11, pp. 4945-4953, 2000.

[30] G. Talbot, E. Topp, M. F. Palin, and D. I. Massé, "Evaluation of molecular methods used for establishing the interactions and functions of microorganisms in anaerobic bioreactors," Water Research, vol. 42, no. 3, pp. 513-537, 2008.

[31] C. J. Tang, P. Zheng, Q. Mahmood, and J. W. Chen, "Start-up and inhibition analysis of the Anammox process seeded with anaerobic granular sludge," Journal of Industrial Microbiology and Biotechnology, vol. 36, no. 8, pp. 1093-1100, 2009.

[32] A. Abeliovich, "Transformations of ammonia and the environmental impact of nitrifying bacteria," Biodegradation, vol. 3, no. 2-3, pp. 255-264, 1992.

[33] H. Imachi, Y. Sekiguchi, Y. Kamagata, A. Ohashi, and H. Harada, "Cultivation and in situ detection of a thermophilic bacterium capable of oxidizing propionate in syntrophic association with hydrogenotrophic methanogens in a thermophilic methanogenic granular sludge," Applied and Environmental Microbiology, vol. 66, no. 8, pp. 3608-3615, 2000.

[34] M. Hatamoto, H. Imachi, S. Fukayo, A. Ohashi, and H. Harada, "Syntrophomonas palmitatica sp. nov., an anaerobic syntrophic, long-chain fatty-acid-oxidizing bacterium isolated from methanogenic sludge," International Journal of Systematic and Evolutionary Microbiology, vol. 57, no. 9, pp. $2137-$ 2142, 2007. 
[35] J. T. Brosnan and M. E. Brosnan, "The sulfur-containing amino acids: an overview," Journal of Nutrition, vol. 136, no. 6, pp. 16365-16405, 2006.

[36] L. H. Lash, J. W. Fisher, J. C. Lipscomb, and J. C. Parker, “'Metabolism of trichloroethylene," Environmental Health Perspectives, vol. 108, no. 2, pp. 177-200, 2000.

[37] A. Siggins, A. M. Enright, and V. O'Flaherty, “Temperature dependent $\left(37-15^{\circ} \mathrm{C}\right)$ anaerobic digestion of a trichloroethylene-contaminated wastewater," Bioresource Technology, vol. 102, no. 17, pp. 7645-7656, 2011.

[38] A. Siggins, A. M. Enright, and V. O’Flaherty, “Low-temperature $\left(7^{\circ} \mathrm{C}\right)$ anaerobic treatment of a trichloroethylene-contaminated wastewater: microbial community development," Water Research, vol. 45, no. 13, pp. 4035-4046, 2011.

[39] F. Bastida, C. Nicolás, J. L. Moreno, T. Hernández, and C. García, "Tracing changes in the microbial community of a hydrocarbon-polluted soil by culture-dependent proteomics," Pedosphere, vol. 20, no. 4, pp. 479-485, 2010.

[40] M. A. Williams, E. B. Taylor, and H. P. Mula, "Metaproteomic characterization of a soil microbial community following carbon amendment," Soil Biology and Biochemistry, vol. 42, no. 7, pp. 1148-1156, 2010.

[41] P. Wilmes, M. Wexler, and P. L. Bond, "Metaproteomics provides functional insight into activated sludge wastewater treatment," PLoS ONE, vol. 3, no. 3, Article ID e1778, 2008.

[42] P. Wilmes, A. F. Andersson, M. G. Lefsrud et al., "Community proteogenomics highlights microbial strain-variant protein expression within activated sludge performing enhanced biological phosphorus removal," The ISME Journal, vol. 2, no. 8, pp. 853-864, 2008.

[43] A. Fernández, S. Huang, S. Seston et al., "How stable is stable? Function versus community composition," Applied and Environmental Microbiology, vol. 65, no. 8, pp. 3697-3704, 1999.

[44] S. McHugh, G. Collins, T. Mahony, and V. O’Flaherty, “Biofilm reactor technology for low temperature anaerobic waste treatment: microbiology and process characteristics," Water Science and Technology, vol. 52, no. 7, pp. 107-113, 2005. 

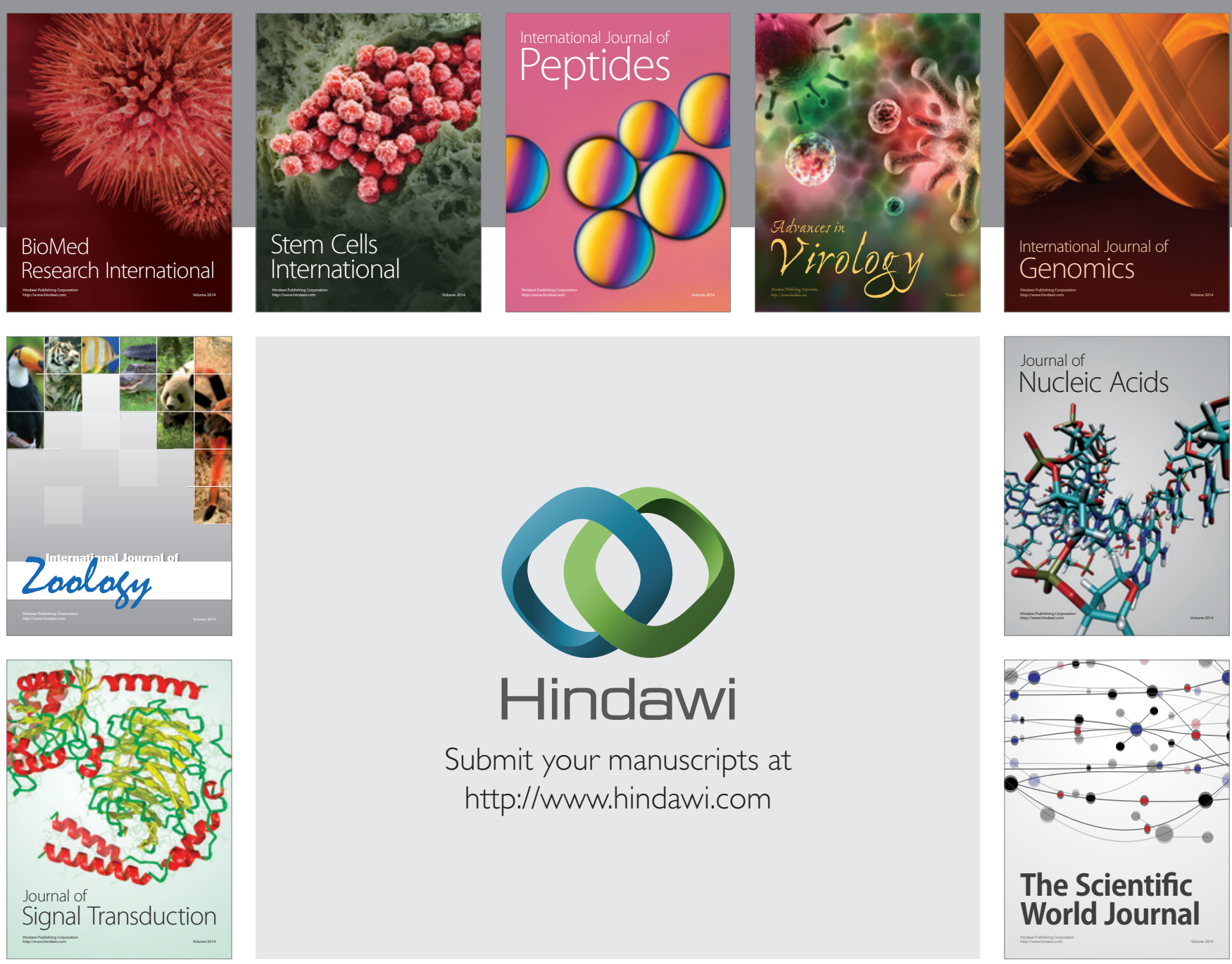

Submit your manuscripts at

http://www.hindawi.com
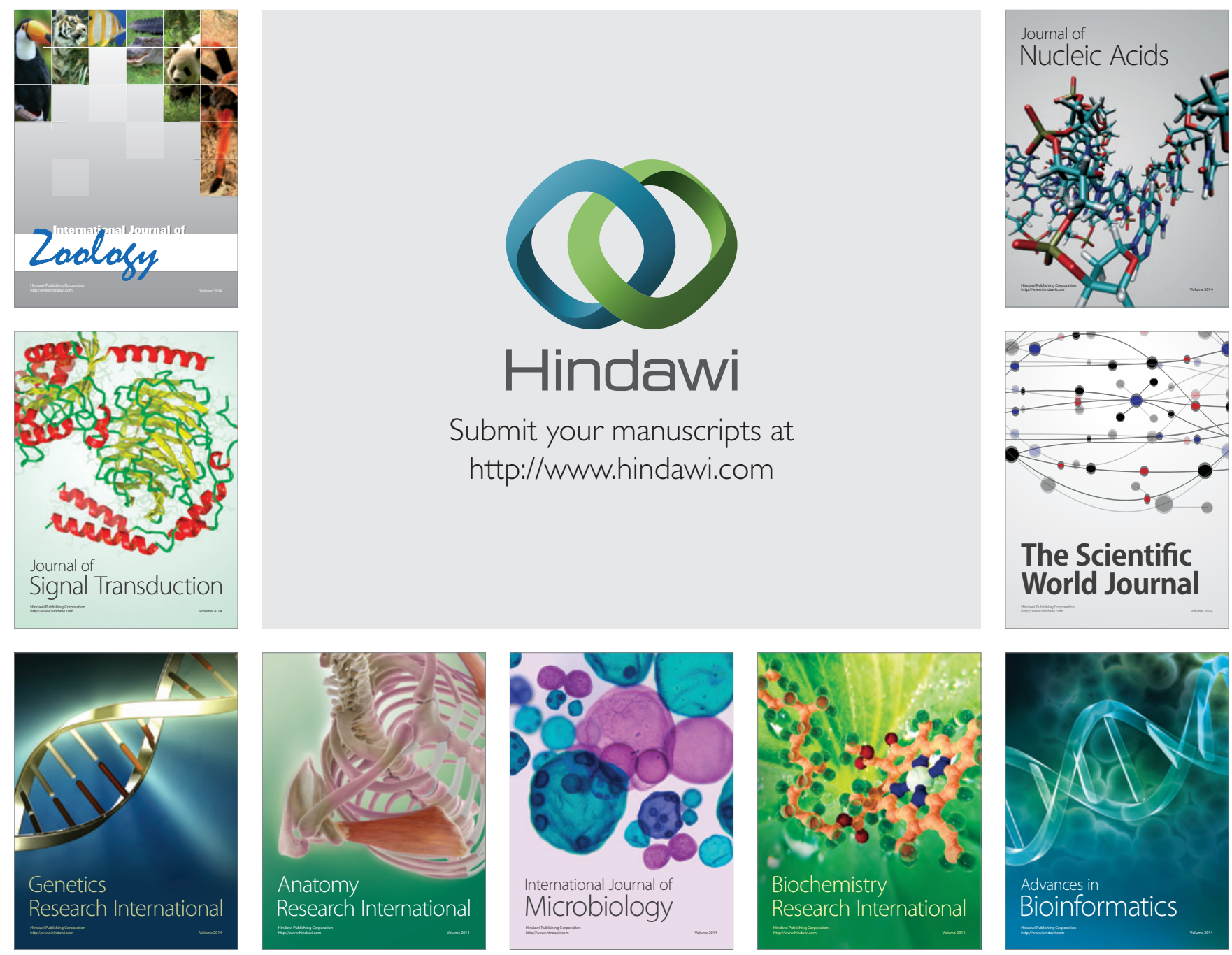

The Scientific World Journal
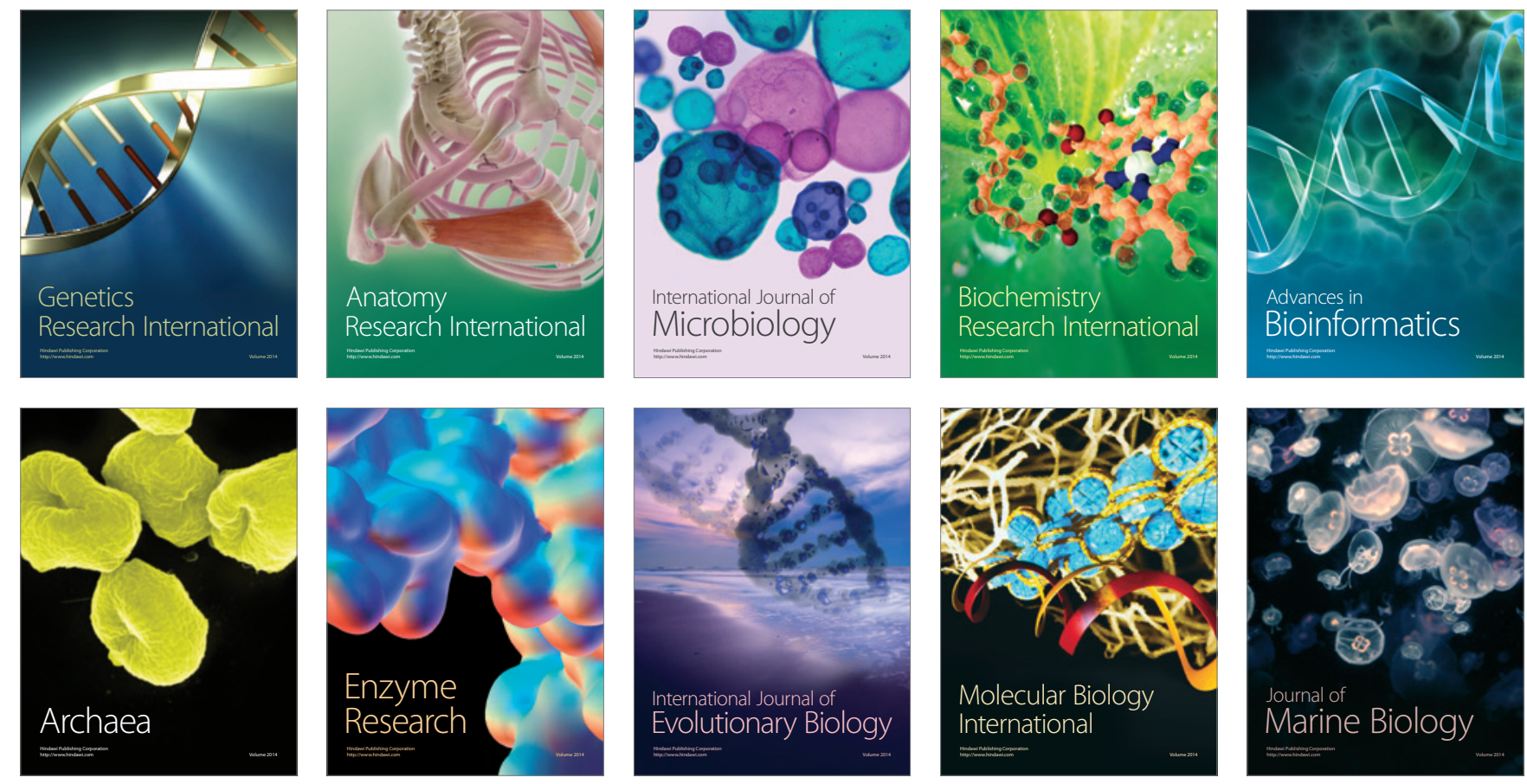